\title{
2. Between a rock and a hard place: self-determination, mainstreaming and Indigenous community governance
}

\section{Janet Hunt}

The first few years of the new century saw major change in the Australian Government's approach to Indigenous affairs. These developments combined with simultaneous policy shifts in State and Territory jurisdictions to create a period of enormous flux and uncertainty in Indigenous communities and organisations. This chapter aims to help readers understand these changes and the resulting challenges facing the Indigenous community governance bodies involved in our research. Subsequent chapters will indicate that Indigenous people and their organisations actively engaged through this period, trying to manoeuvre their way through these new arrangements towards their own goals. The changes presented opportunities as well as constraints, but this chapter will argue that there is an underlying contradiction that the organisations confront. They are, in a sense, between a rock and a hard place: the assumptions and principles of self-determination underlying the policy environment in which many of them were created have changed. Some new ideas like 'mainstreaming' have been introduced and organisations are finding themselves caught at an uncomfortable intersection between communities operating with one set of assumptions, and governments another. They are also squeezed in the shifting policy space between jurisdictions as different interests exert their influence around them. These organisations are the intercultural space where different 'framings' of the governance challenge (cf. Leach et al. 2007) meet or, at times, collide. At the end of 2007, as this research concluded, a change of government at the national level signalled the potential for a more productive engagement with Indigenous people to address the challenges this paper outlines.

\section{Background}

Between the early 1970s and the mid 1990s, under both Labor and Coalition Governments, many of the organisational arrangements for Indigenous community governance developed under policies favourable to the principle of Indigenous self-determination. Although this principle was enormously circumscribed in practice, and self-management might better describe what actually occurred (Moreton-Robinson 2007), the period saw the creation of an 'Indigenous sector' across the country and diverse land rights regimes in a number of jurisdictions. The sector comprised statutory bodies such as land councils, native title bodies, Aboriginal and Torres Strait Islander Commission 
(ATSIC) Regional Councils, community government councils acting as local governments, and several thousand Indigenous associations and corporations providing legal, employment, health, housing, education and many other services, which burgeoned across the country (Rowse 2005). This diverse expression of Indigenous agency and collective effort to take greater control over Indigenous lives was encouraged by key pieces of legislation ${ }^{1}$ and by governments' program arrangements. The idea that Indigenous peoples' organisations may be best placed to address Indigenous problems was well-supported through special Indigenous programs, which funded Indigenous-controlled services. The mosaic of organisations also reflected the desire of Aboriginal people for a very local level of organisation and representation. Nevertheless, the establishment of ATSIC in 1990 provided an important form of Indigenous representation at the national level, albeit government-designed and under Ministerial control (Morrisey 2006). Though severely constrained by the complex federal legislative and policy context, the lack of Indigenous economic independence, the poor educational levels of many Indigenous people, and the limited national efforts towards Indigenous capacity building, self-determination as a principle was well accepted, if implemented without adequate support and in quite different ways from the Torres Strait to remote communities and urban settings (House of Representatives Standing Committee on Aboriginal Affairs (HRSCAA) 1990). As a result, it did not deliver quickly enough on the aspirations of those who championed and supported it. The statistics on Indigenous disadvantage seemed hard to budge, and the rapid growth of a youthful population with poor education and health, few employment prospects, and many associated social problems seemed, to many, to demand a new response.

\section{Changing the arrangements}

Change began with the election in 1996 of the Howard Coalition Government (P. Dodson 1996; Dodson and Pritchard 1998). This occurred just over half-way through the 10-year national reconciliation process led by the Council for Aboriginal Reconciliation (CAR), which was expected to lead to a negotiated agreement between Indigenous and other Australians. CAR was due to report to the national parliament in 2000. By then, for a variety of reasons, Australian Government relations with Indigenous Australia were deteriorating (Sanders 2006). From the outset, the Howard Government had been promoting what became known as 'practical reconciliation' - essentially focusing on Indigenous socioeconomic disadvantage (Aboriginal and Torres Strait Islander Social Justice Commissioner (ATSISJC) 2000, 2001). The Government's approach was to emphasise that, after many years of self-determination policies and focus on 'rights' (including land rights), Indigenous social and economic outcomes

${ }^{1}$ For example: Aboriginal Land Rights (Northern Territory) Act 1976 (Cth); Aboriginal Land Rights Act 1983 (NSW); Aboriginal Councils and Associations Act 1976 (Cth); Native Title Act 1993 (Cth). 
remained woefully below the levels of other Australians, and these earlier ideas were now off the agenda ${ }^{2}$ - despite evidence of at least some gains having been made (Altman 2004). The Government was tackling Indigenous disadvantage as its contribution to the reconciliation decade and would continue this focus in response (Commonwealth of Australia 2002). It was thus highly selective in its response to the Council's recommendations on sustaining the reconciliation process, promoting recognition of Indigenous rights, overcoming disadvantage, and fostering economic independence (CAR 2000). Aboriginal critics directly and implicitly highlighted the false dichotomy implied in the distinction between 'practical reconciliation' and rights-based approaches (Behrendt 2001, 2002; P. Dodson 1996; Dodson and Strelein 2001), but their voices were ignored. Nor was the Government concerned about undermining the very foundation of the concept of reconciliation - the expression of collective responsibility for past wrongs (Gaita 2007).

Thus, in the year 2000 the Council of Australian Governments (COAG) initiated a process to collaborate in addressing Indigenous disadvantage. It established nationally agreed priority outcomes and pledged periodic assessment of progress through Overcoming Indigenous Disadvantage reports (Steering Committee for the Review of Government Service Provision (SCRGSP) 2003, 2007). However, it offered no agreed national plan. Instead, COAG established eight 'whole-of-government' community trials to test new ways of working. Although progress in these was reportedly slow, in mid 2004 the Australian Government announced a set of 'new arrangements' in Indigenous affairs, which appeared to draw from this approach and were to apply nationally (Office of Indigenous Policy Coordination (OIPC) 2005).

The new arrangements involved the abolition of ATSIC, including its network of 35 elected regional councils (ATSISJC 2005b; OIPC 2005; Sanders 2004). Government would no longer work through these representative bodies, but instead would operate in direct partnership with Indigenous communities in a coordinated whole-of-government approach, emphasising Indigenous self-responsibility and mutual obligation (Shergold 2005). Proposed new regional Indigenous consultation arrangements (OIPC 2007) failed to materialise nationally, but the whole-of-government concept was implemented through various new processes or mechanisms, notably the leadership of the Secretaries Group on Indigenous Affairs (Gray and Sanders 2006), a single Indigenous budget, the establishment of Indigenous Coordination Centres (ICCs) in 30 locations around Australia, Shared Responsibility Agreements (SRAs) and Regional Partnership Agreements (RPAs). The idea was to 'harness the mainstream' to address Indigenous disadvantage, an idea reminiscent of one that had been tried-and

\footnotetext{
2 Some years later, the Minister for Indigenous Affairs, the Hon. Amanda Vanstone, put the government's view this way: 'being land-rich but dirt poor is not good enough' (Vanstone 2005).
} 
failed - much earlier (Arabena 2005). Altman (2004) described this 'new' approach as simply moving Indigenous-specific programs to mainstream departments, which themselves had demonstrated little capacity to meet Indigenous needs.

The key new players established in terms of partnerships with Indigenous communities are the ICCs. Their role is to coordinate 'Indigenous-specific programs' and 'negotiate regional and local agreements' (OIPC 2005: 15). These centres are meant to be 'one-stop-shops' for Indigenous interaction with the Australian Government and, ideally, for other jurisdictions as well. But they have struggled to satisfy Indigenous communities in this regard, with some communities concerned about a lack of ICC activity or access, and others experiencing a proliferation of new departmental relationships, funding applications and reporting processes (ATSISJC 2007a; Gilligan 2006; Gray and Sanders 2006; Hunt and Smith 2006; Jeffries 2006; McCarthy 2006). Obviously, the 'silo' behaviour of different departments, which whole-of-government approaches were meant to overcome, was proving difficult to change.

Self-determination gave way to 'sharing responsibility'. SRAs became the 'front line' of the partnership between government and Indigenous communities (Secretaries Group on Indigenous Affairs (SGIA) 2005). These local agreements sit within a broader context of 'mutual obligation' policy, as the key policy tools for a new direct conversation with Indigenous communities (Vanstone 2005). There have been many criticisms of SRAs, notably that government is by-passing competent Aboriginal organisations with existing capacity in order to negotiate directly with families and individual communities (ATSISJC 2005a, 2005b; McCausland 2005a, 2005b). With less than 250 negotiated in four years, and many of the easiest to finalise agreed first, SRAs appeared from the outset to be a very cost-inefficient and patchy means of delivering services to Indigenous Australians across the nation, even if some communities were relatively satisfied with them (ATSISJC 2007a). ${ }^{3}$ SRAs obviously contribute to the existing burden of 'red tape' (Morgan, Disney and Associates 2006a). More significantly, SRAs suggest that Aboriginal people can have a voice in a limited range of local matters, but remain voiceless and unrepresented on the far more significant backlogs of housing, health, education and other essential services due to them as citizens. The development of RPAs, which appeared by 2007 to be replacing the focus on SRAs, has been much slower, however, with less than a handful negotiated by early 2008 (Australian Government 2008); their responsiveness to Indigenous priorities is already being questioned (ATSISJC 2007b; Shire of Naaanyatjarruku and Ngaanyatjarra Council 2007).

\footnotetext{
${ }^{3}$ There are over 1200 discrete Indigenous communities, without consideration of the regional and urban populations living in mixed settlements (ABS 2001).
} 


\section{Development discourses and the alleged 'failure' of self-determination}

While these changes were proceeding, the discourse of 'failure' about past policies strengthened. Concern about social problems in Aboriginal communities is neither new nor confined to people or groups of any particular political persuasion (Hinkson 2007). However, by 2005, public debate about the 'failure' of self-determination, and suggestions that this had led to a form of separatism, were being escalated by those associated with right-wing think tanks and associations such as the Centre for Independent Studies and the Bennelong Society (Dillon 2005; Johns 2006), as well as by the Australian Government itself (Vanstone 2005).

When Minister Brough announced his 'Blueprint for Action in Indigenous Affairs' (Brough 2006a), his key messages were about giving Indigenous Australians equitable access to services on the same basis as other Australians, and removing barriers to economic opportunity. Asserting that culture should not 'stand in the way of progress', the Minister emphasised that individual, not community, decision making was critical, and suggested that the term 'partnership' would:

signal the beginning of a redefinition of relationships ... to a point where responsibilities between governments, Indigenous people and other Australians are better aligned to normal Australian life ... We need to move beyond the fact that because a community is largely Indigenous that state and local governments relinquish their responsibilities for providing municipal and other basic services (Brough 2006a: 3-4).

Whilst such debates about treating Aboriginal people like all other Australian citizens, or treating them differently based on their group identity, have featured over decades of Indigenous policy (Attwood 2003), at this time the Commonwealth was clearly signalling that it planned to shift some financial responsibilities for remote Indigenous communities, which it had historically supported, to other jurisdictions. The broader strategy was three-pronged. In urban areas mainstream services would be improved to cater better for Indigenous people and improve their access to jobs. In remote areas the Government would be 'working with other governments to improve standards of service and to open these communities to the broader Australian community and the market economy' (Brough 2006a: 9). Some 'priority communities' would be the subject of 'intensive intervention' (ibid.), land tenure changes would be introduced, and 'normal' economic activity and home ownership would be encouraged. Thus, collective self-determination was being rejected and replaced by emphasis on an individual's ability to choose a particular way of life (Brough 2006a; Dillon 
2005), notably one which embraced the 'mainstream' ${ }^{4}$ The 'mainstream' implied full engagement in a market economy. While for many Indigenous people who have experienced considerable exclusion from such economic opportunities this may be welcome, the features of Aboriginal life which marked out 'difference', such as communal land ownership and living on remote 'homelands', came under threat.

The Howard Government argued that communal land ownership was a key brake on economic development, that individual property rights were essential, and that reform of land tenure in Aboriginal townships under the Aboriginal Land Rights (Northern Territory) Act 1976 (Cth) (ALRA) to allow 'head leases' was necessary. In fact, changes to this Act had already been passed to 'provide more choice and opportunity for Aboriginal people in the Northern Territory ... and enable Aboriginal communities to operate like normal Australian towns' (Brough 2006b). Some 'intensive interventions' were also already underway, generating controversy about land tenure arrangements (Scrymgour 2007). Commonwealth funding for Indigenous home ownership to all jurisdictions in Australia was also to require 99-year head leases on Aboriginal land (ATSISJC 2007b). As Dodson and McCarthy (2006: 26) concluded, the changes to the ALRA were 'squarely aimed at drawing residents in remote communities away from real communal ownership of land and into individuated relationships with the wider economy'. The permit system, which enabled Aboriginal people to control access to their freehold land, was also to be changed, as it apparently 'hindered effective engagement between Aboriginal people and the Australian economy' (FaCSIA 2006: 4), an argument strongly disputed by David Ross, director of the Central Land Council, a major body that issued permits (Ross 2007).

If the first set of changes were designed to foster economic development on Indigenous land, the second tranche was to force greater Indigenous mobility to existing job markets. According to critics, Indigenous Australians were insular, indulgent, and needed to move into modern Australian society:

If people want goods and services that a modern economy can provide, they will have to generate an income in order to purchase them. In order to generate an income they will have to work. If work is not available where they live, they will have to move to find it (Johns 2006: 1).

Changes to labour market and income support programs that would affect individual behaviour were seen as the solution. In other words, Indigenous Australians needed to accept the tenets of liberal democracy and individual property rights, and fully embrace the market and modernisation. They were to be pressured to assimilate. The fact that many Indigenous people already

\footnotetext{
4 Of course, self-determination for a people was never in conflict with an individual's right to choose a way of life-indeed it was intended to strengthen the choices available to individuals within defined groups, whose rights have often been curtailed.
} 
living in close proximity to employment opportunities in urban centres remain poor and experience high rates of unemployment, seemed to be overlooked (Taylor 2006).

\section{Indigenous discourses}

These changes were not driven by the Government alone. The Indigenous leadership network, which had worked together closely in the early 1990s, was no longer of one voice. Some key Indigenous individuals were actively promoting many of these policy changes, to both the Coalition Government and the Labor Party, then in Opposition. The most prominent was Noel Pearson. He vigorously promoted a change to perverse economic incentives, arguing passionately that welfare was killing his people in Cape York. He argued that social norms had broken down, and that nothing less than radical welfare reform was required to ensure that Aboriginal people regained their dignity, took responsibility for their lives and those of the next generation, and indeed survived as a people (Pearson 2000, 2005b). Drawing on ideas from development economist Amartya Sen (1999), Pearson was concerned about people's capability to be self-determining and to make choices through liberation from alcohol dependence, better education, exposure to the 'mainstream', and through economic development of their lands (Pearson 2000, 2005b). ${ }^{5}$ Pearson argued for Indigenous mobility and the education necessary to enable young people to move for work. He also urged reform of the Community Development Employment Projects (CDEP) program which, combined with other family payments, he saw as providing a disincentive to people entering the so-called 'real economy', accessing the formal job market or generating businesses (Pearson 2005a, 2006).

Pearson nevertheless remained a supporter of Aboriginal native title, of collective ownership of land and the rights of Indigenous people, although he downplayed these issues. He also argued for engagement with Aboriginal organisations and leaders. His argument was essentially about re-balancing collective rights with individual responsibilities, and he asserted that social dysfunction was a higher priority to address than land rights issues (Cape York Institute (CYI) 2007; Pearson 2007a, 2007b). Pearson's views about Indigenous rights as first peoples, the value of Indigenous cultural identity and the role of Indigenous organisations, clearly differed from Government's, but his other ideas were sufficiently close to theirs for him to gain considerable Government support for his initiatives. He was appointed an Adviser on Welfare Reform to the Prime Minister, and the 'Cape York Agenda' began to dominate national policy discourse. His approach

\footnotetext{
5 Sen's (1999) work, though valuable in broadening the concept of development beyond narrow economics, seems to neglect the interaction between individuals and social structures, and he views individual 'freedom' as a value overriding all others. Sen's theory may seriously underestimate the discord between these assumptions and the relationships and obligations that underpin contemporary Indigenous societies and worldviews, and may thus fail to provide a strong basis for successful Indigenous development (Adams 2007).
} 
was not without its critics (Behrendt 2007; Calma 2007; Hart, Herbert and Tripcony 2004; Education and Health Standing Committee (EHSC) 2007a), and Government adopted it selectively, ignoring the Indigenous rights, cultural identity and Indigenous organisational leadership aspects.

Other Indigenous individuals, including Warren Mundine, a senior figure in the Australian Labor Party, accepted the Coalition Government's invitation to join a new National Indigenous Council (NIC) to advise the Government after ATSIC's abolition in 2004. ${ }^{6}$ Chaired by Western Australian magistrate Sue Gordon, this advisory council supported and gave some legitimacy to the Government's new approach (NIC 2006). Thus, the Government drew on the support of selected Indigenous people who shared its view of the problem. Other Indigenous leaders were marginalised from the national debate, their focus on rights-based approaches characterised as inappropriate in light of the growing sense of past policy failure and current crisis.

A number of specific policy changes highlight some of the key issues under contention. These included the debate about outstations (or 'homelands' communities), as well as the abolition or reform of CDEP and the Community Housing and Infrastructure Program (CHIP).

\section{The Homelands debate}

The debate about collective ownership of land was linked to the issue of the viability of small, remote outstation communities. On a number of occasions, Ministers (see Brough 2006a; Vanstone 2005) and the Prime Minister took the opportunity to emphasise that they perceived Aboriginal people living in remote settlements as enduring a second-rate existence in undesirable segregation from mainstream society:

The right of an Australian to live on remote communal land and to speak an Indigenous language is no right at all if it is accompanied by grinding poverty, overcrowding, poor health, community violence and alienation from mainstream Australian society. Reconciliation has little meaning in a narrative of separateness from that society (Howard 2007a: 2).

Support for these views came from the book Lands of Shame (Hughes 2007), a Centre for Independent Studies publication, which argued that 'exceptionalist' policies that enabled Indigenous people to subsist in 'living museums' had left Indigenous people illiterate, without economic sustenance, welfare dependent and without access to the protections and standards of living expected by other Australians. But while conditions may be inadequate, evidence about homeland outstations suggests that relative to larger Indigenous communities, housing is less crowded, median income is similar, employment and health is better, and

\footnotetext{
${ }^{6}$ He later resigned under pressure from within the Labor Party over conflicts of interest and policy.
} 
most have good access to essential infrastructure services, such as clean water and electricity (Altman 2006). Customary wildlife harvesting is also likely to be greater, thus livelihoods may be better than income data would reveal, while natural and cultural resource management activities associated with homelands contribute significantly to positive health outcomes (Burgess and Johnstone 2007).

Furthermore, it became clear that if Aboriginal people choose to remain on the lands to which they returned so determinedly two or three decades before, the Australian Government was no longer going to support them (Howard 2007a). Nor were State/Territory Governments clear about how they would move forward from a legacy of several levels of government conflict about, and abdication of, their responsibilities to Aboriginal citizens, particularly in remote regions (EHSC 2007b). The Law Reform Commission of Western Australia (2006: 352) was one of the most recent organisations to recognise this:

The rhetoric of self determination has, in the past, allowed governments to abdicate their responsibilities to provide services that are an entitlement of citizenship and which non-Aboriginal Australians take for granted.

Community governance in such remote locations was clearly going to be squeezed, with poorly-funded organisations attempting to provide continuity of services in such a shifting policy and funding environment.

\section{Mainstreaming CDEP and CHIP}

ATSIC's two largest programs, which were 'mainstreamed' in mid 2004, were CDEP and CHIP. Both programs functioned through a wide network of Aboriginal-controlled organisations, and CDEP had around 35000 participants. The CDEP transfer in particular was to have dramatic impacts.

The handover of CDEP to the Department of Employment and Workplace Relations (DEWR) brought it into close contact with other mainstream labour market programs. The 'old' CDEP model, which offered close to guaranteed, relatively flexible, annual funding for community organisations, and provided continuing support for a broad range of community-defined work for participants (albeit with none of the usual benefits and conditions of regular employment or superannuation entitlements), was gradually replaced with a model in which contracts specified clear job targets, defined what work was more narrowly (e.g. excluding some cultural work), and did not provide continuing job subsidy support $^{7}$ (Sanders 2007a, 2007b). DEWR was transforming CDEP into a narrower skill development and employment program, more reflective of that department's

\footnotetext{
7 'Changes to CDEP', Department of Employment and Workplace Relations (DEWR) website, available at $\quad<$ http://www.workplace.gov.au/workplace/Category/SchemesInitiatives/IndigenousProgs/ ChangestoCDEP.htm $>$ [accessed 17/06/07].
} 
wider employment philosophy. ${ }^{8}$ Around 60 urban and regional CDEPs across Australia were closed in mid 2007, ${ }^{9}$ and another 50 in the Northern Territory (NT) were expected to close by mid 2008, until some of these were given a reprieve with the late 2007 change of Australian Government (Brough and Hockey 2007; Koori Mail 2007; Murdoch 2007). CDEP activity underpinned a number of other government programs and economic development initiatives with Indigenous people, among them the Indigenous Protected Areas Scheme (Gilligan 2006), art programs, municipal services, and the activities of outstation resource agencies, yet the implications of DEWR's changed approach for these activities seemed not to have been fully considered. However, some 800 former CDEP jobs in government programs were fully funded by the Australian Government (ABC News 2007a, 2007b; Altman 2007a; Brough 2007; Hunt and Smith 2007). Clearly, the Australian Government expected State and Territory Governments to take up more of the employment challenge. In December 2007, the Labor Government transferred responsibility for CDEP to the new Department of Families, Housing, Community Services and Indigenous Affairs (FaHCSIA), indicating some rethinking about the program for the future.

In May 2007, the Australian Government also announced the abolition of the major Aboriginal housing scheme, CHIP, which had been managed by the Department of Families and Community Services and Indigenous Affairs (FaCSIA) since July 2004, and delivered by State and Territory Governments, local government and around 600 Aboriginal community housing organisations. An independent review had found extensive problems with the program (PricewaterhouseCoopers 2007). It is being replaced by new arrangements that involve mainstreaming Indigenous housing into public housing programs, policies to encourage Indigenous people to move to new public housing in locations where education, health and other services are available (i.e. no more new housing at outstations or homelands), and encouraging home ownership (Brough 2007). Whilst Dillon and Westbury (2007) argue strongly that parallel housing schemes for Indigenous and other Australians have seriously disadvantaged Indigenous people, ${ }^{10}$ the impact of the policy announcement is nevertheless the redundancy of many Indigenous community housing sector organisations.

This transformation of the CDEP and community housing programs has clearly impacted on the Indigenous organisational landscape in some regions, as smaller

\footnotetext{
8 'Community Development Employment Projects (CDEP) Programme', workplace.gov.au website, Australian Government, available at <http://www.workplace.gov.au/workplace/Programmes/ IndigenousProgs/Community+Development+Employment+Projects+\%28CDEP\%29+Programme/> [accessed 17 June 2007].

9 Other CDEPs not wishing to, or unable to, meet new program requirements lost funding. It is unclear how many successfully tendered for the Structured Training and Employment Program (STEP) (Cth), designed to prepare people for jobs.

10 Dillon and Westbury (2007), however, disagreed about stopping new housing and infrastructure in outstations.
} 
organisations close down, coalesce or become dormant, and larger ones juggle new responsibilities. As this organisational adjustment process has been occurring (which at best may lead over time to fewer organisations with greater capacity, or at worst may leave communities without programs and services), other programs have inevitably, if unintentionally, been affected (Altman 2007a).

\section{The outcomes of the COAG trials}

In April 2007, evaluations of the COAG trials were quietly released. Despite some diplomatic language, the reports revealed many problems; although there had been more progress at some sites than others, achievements were relatively limited in light of the significant resources dedicated to the trials. The evaluations identified the importance of building relationships and developing trust for successful partnerships, yet indicated that a number of factors militated against this. The trials had not emphasised enough how governments would need to work differently from how they had worked in the past to address community priorities; clearly insufficient attention had been given to new governance arrangements (Morgan, Disney and Associates 2006b).

The trials showed that an urgent priority is to address the capacity constraints within and between governments engaging with Indigenous communities. There is a need for clear, agreed policy frameworks and a simplification of program and funding arrangements, cultural change and staff development for whole-of-government work in Indigenous communities, as well as realistic expectations. They demonstrated that a successful framework needs to enable Indigenous people to have sustained, properly resourced opportunities to build their governance and participate in planning and decision-making. Building community governance and capacity at local and regional level through community development approaches is seen as a high priority for partnership working - to provide the foundation stone on which effective partnerships and programs can be built.

The COAG experience indicates that the factors that frustrated earlier self-determination policies were equally capable of frustrating positive outcomes from the 'new arrangements'. In 1991, the Royal Commission into Aboriginal Deaths in Custody (RCIADIC) had recognised that the years of self-determination policy were 'a cruel hoax' for Aboriginal people:

They were not really being offered self-determination, just the tantalising hint of it. Instead they were being bequeathed the administrative mess which non-Aboriginal people had left, and were being told to fix it up. It was their mess now (RCIADIC 1991 Vol 4: 27.6.1).

That mess was the multitude of different funding arrangements, the inter-departmental competition, or what amounted to a 'ludicrously complicated funding super-structure' (RCIADIC 1991 Vol 4: 27.3.13), which remained the 
source of many problems; 15 years after the Royal Commission it was still a non-Indigenous responsibility to fix it. Yet governments seemed unable to. Inter-governmental rivalries, arguments about funding levels and responsibilities, and political posturing frequently combined to frustrate improvements. As Dillon and Westbury (2007: 208) argue, '[t]here has been a fundamental failure in the governance of governments in relation to Australian Indigenous affairs'.

However, while the mainstreaming approach to service delivery applied across the nation, with the consequent tendency to circumvent, undermine and de-fund Indigenous organisations, ${ }^{11}$ there was even greater change to come in the NT, which accounts for some 10 per cent of the national Indigenous population.

\section{The 2007 intervention in the NT}

By June 2007, these policy changes in Indigenous Australia were well underway, yet barely noticed in 'mainstream Australia', when a dramatic announcement by the Prime Minister hit the headlines. ${ }^{12}$ Within days of the Little Children are Sacred Report (Anderson and Wild 2007) being publicly released in the NT, the Commonwealth Government moved with an intervention in the Territory, which it called a national emergency and likened to Hurricane Katrina (Howard 2007b). Others referred to it as 'martial law' (P. Dodson 2007; Smith 2007b). The intervention had a number of elements, with law and order 'a central focus', and the army called in to provide logistic and other support. These elements included an immediate increase in policing levels, widespread alcohol restrictions on Aboriginal land (much of which was already 'dry'), medical examinations of Indigenous children, quarantining of 50 per cent of income support for food and other essentials, enforced school attendance, abolition of the permit system for common areas and road corridors on Aboriginal lands, and government-controlled leases over Aboriginal townships for five years, with administrators appointed to each township (Howard 2007b). Initially, 60 Indigenous communities were indicated but the number increased to 73 .

Responses to this announcement ranged from welcoming the fact that the national Government had finally recognised the crisis facing Aboriginal communities

\footnotetext{
${ }^{11}$ The only Indigenous community-controlled sector that remained relatively unscathed was the health sector, although it was challenged to meet the accountability standards and processes associated with new public management approaches, while also meeting the expectations of its Indigenous clients for a more holistic health approach.

12 In 2006, the outspokenness of an Alice Springs Crown Prosecutor, a media exposé of violence, and the Minister's allegations of paedophilia in a central Australian community had been the trigger for a flurry of media and political activity on these issues, culminating in a Ministerial Summit on Family Violence held in Canberra in June. The almost total absence of Indigenous participants in that summit sent a message that the Government was not prepared to work in partnership with Indigenous people with expertise in these issues. In June 2007, the Government argued that a delay by the NT Government in response to a major report into child sexual abuse in the NT forced it to act. The Commonwealth suggested that it was only the persistence of the Aboriginal Affairs Minister in 2006 that had led the NT Government to undertake this enquiry in the first place.
} 
and responded, to sharp criticism at the racial basis and centralist response (Altman and Hinkson 2007; Atkinson 2007; CLC 2007; Grattan 2007). Many who welcomed the fact that a response was being made were nevertheless sceptical about the motives, the effectiveness and sustainability of the approach, particularly the very top-down and militaristic style (Anderson 2007). This was ironic, since the very first recommendation of the report that the Government was using to justify its actions said: 'It is critical that both governments commit to genuine consultation with Aboriginal people in designing initiatives for Aboriginal communities' (Anderson and Wild 2007: 22).

Across the NT there was generally a high level of confusion and some fear about the implications of the announcement. While improved police and medical services had long been called for and were generally welcomed in the short-term, there was fierce Indigenous opposition to some of the measures, particularly in relation to land and the permit system, which most argued were unrelated to the issue of child protection. As Patrick Dodson observed, the ALRA:

was the first expression of the constitutional powers mandated by the 1967 referendum for the Australian Parliament to make laws for Aboriginal people ... The Act liberated Aboriginal people in the Northern Territory from their subordinate and colonial status and became an inspiration for a raft of Aboriginal land legislation that has been passed in every Australian jurisdiction with the exception of Western Australia (P. Dodson 2007: 9). ${ }^{13}$

The attack on the ALRA was seen as a racist attack on self-determination and on Indigenous people's right to a distinctive and different way of life. A coalition of NT Aboriginal organisations prepared a detailed response to the intervention, critiquing the Government's actions and putting forward their own proposals to tackle the deep-seated problems based on a community-driven, evidence-based approach, in partnership with governments (Combined Aboriginal Organisations of the Northern Territory (CAONT) 2007). The proposed abolition of the CDEP added to the radical transformation being suggested. The Government justified it both in terms of the need to create 'real jobs' and in terms of the need to be able quarantine welfare payments (Brough and Hockey 2007). The 'real jobs' to be created by governments (estimated at 1600), while very welcome, would not replace $7500 \mathrm{CDEP}$ positions to be abolished. Those people not transferred to jobs would find their income drop as 'Work for the Dole' participants.

From a governance point of view, the Australian Government's June 2007 announcement was a dramatic development that strongly reflected a triumph

\footnotetext{
13 Technically this is not quite correct as the ALRA could be justified under the Commonwealth 'Territories' Power. However, the fact that Patrick Dodson sees and reports it this way is a powerful reminder of the symbolic importance of the 1967 constitutional change.
} 
for the conservative think tanks and their assimilationist approach. As Patrick Dodson recognised:

They have asserted that communal land ownership and governance structures that reflect Indigenous traditional decision-making, imprisons Indigenous people in welfare ghettos and locks them out of the benefits of modernity (P. Dodson 2007: 9).

Furthermore, in contrast to earlier collaborative 'partnership' approaches with both the NT Government and Indigenous leaders, it was a return to command-and-control-style hierarchical governance (Davis and Rhodes 2000; Rhodes 2005), as well as a complete reversal of any remnants of self-determination for Indigenous Australians. Indigenous governance was to be shunted aside while public service administrators with extraordinary powers took over again (Siewart 2007). While the intervention and subsequent announcements clearly deployed considerable additional resources for NT Indigenous communities, the cost-effectiveness and sustainable impact of the strategies employed are open to question.

The intervention also coincided with a period of local government reform in the NT, which had begun in 2003 (Smith 2004) and already undergone policy change in October 2006. A shift from a relatively bottom-up process of regional authority development based on culturally-defined and negotiated boundaries was shelved in favour of nine proposed shires, almost all of which were considerably larger than existing proposals, and incorporated non-Indigenous landholders and small urban areas (Smith 2007a, 2007b). The future of many community government councils was limited or unclear, as their roles were to be largely taken over by the new regional shires. The combined raft of Federal and NT Government changes added up to a context of extraordinary flux and uncertainty for many Indigenous organisations.

\section{Governance complexity and contestation}

The picture that emerges is one of continued complexity and policy contestation in Indigenous governance. The period during which the case study research was undertaken is one more iteration of the continuing tensions that arise from the false dichotomy of treating Indigenous people as equal citizens or treating them as holders of special Indigenous rights. The pendulum has swung heavily towards treating them as individual citizens to be 'brought into the mainstream' and 'normalised' to the dominant way of life. In doing so, it is jeopardising deeply-valued Indigenous rights, especially the right of self-determination. As Kerry Arabena recognised:

The government is ill-equipped to deal with the contemporary political consequences of Indigenous identity (including separate representative structures and inclusive cultural aspirations) and this incapacity 
significantly influences how government treats those who are different. This is the core matter for me. In the new arrangements, Aboriginal and Torres Strait Islander peoples are beholden to government, who determines whether we can control our own affairs (Arabena 2005: 28).

The Indigenous Community Governance Project's research has confirmed that on the ground it is self-determination that Indigenous people are still seeking. They may call it 'self-control' or 'independence from government', but fundamentally they are striving to gain greater control over their lives and to promote the kind of development that they value (Hunt and Smith 2007). In 2003, Dodson and Smith argued that Indigenous people should focus on areas of development over which they had control, and they particularly highlighted governing structures, processes, and institutions and local development strategies (Dodson and Smith 2003). Since that was written, some of those governance structures have been dismantled, have collapsed or are struggling in the face of the dramatic changes of the past four years. This has left a significant vacuum of national Indigenous networking and organisational infrastructure to assert Indigenous rights (ATSISJC 2007a).

In the meantime, local and regional organisations within the Indigenous sector have been experiencing considerable tensions as they try to reflect Indigenous aspirations and expectations to be self-determining, while being dependent for funding on mainstream government departments that are applying increasingly incompatible mainstream principles to their Indigenous 'clients'. Indigenous community organisations have become the front line in these inevitable tensions, and this generates conflict and pressures on them, which only the most resilient can manage successfully. RCIADIC warned as early as 1991 that when the government funded services through Indigenous organisations they were subjected to 'minute and suspicious scrutiny' and that the 'whole process of delivery of such services was one of further control of their lives, and not one which offers autonomy' (RCIADIC Vol 4: 20.4.7). If that was true in the previous era, it was more so now. In fact, mainstreaming, as Finlayson (2005) observed, has been accelerating the effects of corporate management policies and competition policy across the board in Indigenous affairs, and this has been most evident in employment programs. Yet Indigenous success stories reflect a different approach, one that has involved government support for Indigenous-driven programs, based on Indigenous values, towards Indigenous-driven goals (Finlayson 2004; Gilligan 2006; Reconciliation Australia 2006).

Furthermore, the experience of the COAG trials demonstrates that for 'mainstreaming' and whole-of-government approaches to work, it has to be in partnership with Indigenous communities and their organisations. It requires effective and legitimate governance in Indigenous communities as well as 
improved governance by governments themselves. If weak or 'dysfunctional' Indigenous governance undermined outcomes in the self-determination era, the same problems are likely to frustrate success in whole-of-government mainstreaming as well, particularly as governments are struggling within themselves to make these new approaches work.

The difficulties facing Indigenous community government are further compounded by tensions between the three levels of government, and particularly State and Federal levels, about their respective responsibilities for service provision in remote areas. An African proverb-'When the elephants fight the grass gets trampled' - sums up the problem. While governments resist each others' attempts to cost-shift, the gaps have to be picked up by seriously under-resourced Indigenous community bodies. The need for a properly planned and negotiated process to address the historical anomalies and shortfalls is urgent. It is something the COAG, with all the governments at the table, could usefully lead as part of its Overcoming Disadvantage strategy. It is to be hoped that the new Australian Government's emphasis on COAG addressing duplication and overlap in jurisdictional responsibilities in Indigenous affairs, and working cooperatively to resolve these, may over time improve the situation (COAG 2007).

Across much of remote Australia, the policy of self-determination faltered when State Governments walked away from their responsibilities, local governments were not engaged, and Indigenous policy was left to the Australian Government, which exercised its role largely through the limited powers and resources of ATSIC. Gradually, as public services and the private sector withdrew from remote regions and ATSIC was axed, a vacuum of governance was left. The long-term strategic development of regional Australia is being ignored (Sanderson 2007). Many levels of government failure have been identified, among them, Commonwealth Grants Commission formulae, which fail to address infrastructure backlogs, the fact that funds allocated to States and Territories on the basis of Indigenous disadvantage are not tied to such expenditure, and the dysfunctional funding arrangements for Indigenous communities (Dillon and Westbury 2007; Morgan, Disney and Associates 2006a; Smith 2007a). Some have argued that the situation has reached crisis proportions and that remote Australia is a 'failed state' (Westbury and Dillon 2006). But this is not a classic failed state in the sense used in international development. The state certainly has failed to provide services, but it creates enormous complexity at the same time, due to the difficult legal, regulatory and policy environment that it has constructed. The state is both absent and ever-present; and the context it creates is not conducive to Indigenous capacity to resolve the challenges Indigenous communities face. Meanwhile, in the urban areas it is clear that mainstream services remain insufficiently responsive to Indigenous needs, while Indigenous-specific services are being dismantled in some sectors or continue to struggle with inadequate, short-term and unreliable funding in others. 
Finally, it seems that 'welfare' has to a large degree substituted for development in Indigenous Australia and this has had very negative effects on people's capacities to be self-determining. Australian governments have used 'welfare' while ignoring the need for remote communities to engage in community and economic development, to create the economic base so essential to genuine self-determination. The drip-feed of welfare has maintained them, but not enabled them to develop in ways they may have wished. Indigenous peoples' idea of CDEP was to try to move in that direction (Whitby 2001), but it was inadequately resourced for the kind of community or economic development necessary. However, Indigenous organisations in the NT pushed again in late 2007 for a greater CDEP focus on community and business development (CDEP Reform 2007). With a welfare economy entrenched, and with very limited support by governments to help communities develop their livelihoods and economic base to date, it is now much harder than it might have been 30 years ago. Nevertheless, it is clear that Indigenous communities are turning their attention to economic development, but using a variety of models and strategies that embrace capitalist entrepreneurialism (Elu 2007; Smith 2006) and hybrid approaches (Altman 2001, $2007 b$ ). Those able to operate from self-generated resources, without government funding, are in a stronger position to demonstrate what their ideas of self-determination look like, even in an era of 'mainstreaming' (Smith 2006).

\section{Conclusion}

There are no guarantees that the approaches introduced since 2004 will be any more successful than the old ones if the wider governance issues facing both Indigenous communities and governments are not addressed. The COAG change agenda requires that governments give their own governance capacities and the 'funding mess' urgent attention if they are to provide the quality of services due to all Indigenous people as citizens. Sustained, facilitative support from governments to strengthen the capacity of Indigenous community governance is also necessary if they are to develop effective partnerships with Indigenous communities to achieve that. There are only limited signs of either happening at present, but a reinvigorated COAG, through its Indigenous Working Group (COAG 2007), could provide the political drive needed.

The conservative national ideology that prevailed through this period left little room for the essential reforms and capacity strengthening support that was needed. By trying to enforce a single definition of the problem (the need to bring Indigenous people into the mainstream) within a complex systems context, power holders in Australia in the last decade have countenanced only a singular solution. Whilst that may meet some Indigenous aspirations, recent literature about governance suggests that an analysis and synthesis of multiple dimensions and knowledge-frameworks about complex social issues is required. The 'framings' of the governance challenges that Indigenous people bring to the fore vary, as 
do the framings of the non-Indigenous players who surround them. Top-down approaches to problems framed by the powerful is the approach that has been exercised increasingly forcefully in Australia throughout the period of this research, at least until late 2007. An alternative is to adopt a more reflexive and adaptive approach to governance, which appreciates the significance of political history, pays attention to power, knowledge and different 'framings' of problems, and leaves open a range of pathways for Indigenous people (Leach et al. 2007). What self-determination means now, and how governance processes can enable it, remains a matter for dialogue. A serious, respectful and engaged conversation is needed between governments and Indigenous people about how to meet diverse Indigenous goals and expectations through a negotiated process at many levels, from the local to the national. A governance of diverse possibilities is required. Whether the new Australian Labor Government can lead such a process remains to be seen.

\section{Acknowledgements}

I am most grateful for insightful comments from Jon Altman, Bill Ivory, Diane Smith and Will Sanders, other colleagues participating in the ICGP researchers' workshop in August 2007, as well as two anonymous referees on earlier versions of this chapter.

\section{References}

ABC News 2007a. 'Scrapping CDEP puts services at risk: NT Govt', ABC Online, 24 July, available at <http://www.abc.net.au/news/stories/2007/07/24/ 1987085.htm $>$ [accessed 24 July 2007]

2007b. 'Scrapping work-for-the dole a disaster: NT Minister', ABC Online, 24 July, available at <http://www.abc.net.au/news/stories/2007/07/24/ 1986458.htm $>$ [accessed 24 July 2007].

Aboriginal and Torres Strait Islander Social Justice Commissioner (ATSISJC) 2000. Social Justice Report 2000, Human Rights and Equal Opportunity Commission (HREOC), Sydney.

-2001. Social Justice Report 2001, HREOC, Sydney. 2005a. Social Justice Report 2004, Report No. 1/2005, HREOC, Sydney.

2005b. Social Justice Report 2005, Report No. 3/2005, HREOC, Sydney.

-2007a. Social Justice Report 2006, Report No. 1/2007, HREOC, Sydney. 2007b. Native Title Report 2006, Report No. 2/2007, HREOC, Sydney.

Adams, A. 2007. The Individual and Social Transformation: A Critique of the Capability Approach, MA Thesis, ANU, Canberra. 
Altman, J. C. 2001. 'Sustainable development options on Aboriginal land: the hybrid economy in the twenty-first century', CAEPR Discussion Paper No. 226, CAEPR, ANU, Canberra.

2004. 'Practical reconciliation and the new mainstreaming: will it make a difference to Indigenous Australians?', Dialogue, 2: 35-45, Academy of the Social Sciences, Canberra.

2006. 'In search of an outstations policy for Indigenous Australians', CAEPR Working Paper No. 34, CAEPR, ANU, Canberra.

2007a. 'Neo-paternalism and the destruction of $\mathrm{CDEP}^{\prime}$, Arena, August-September, 90: 33-35.

-2007b. 'Alleviating poverty in remote Indigenous Australia: the role of the hybrid economy', Development Bulletin, 72: 47-51.

— and Hinkson, M. (eds) 2007. Coercive Reconciliation: Stabilise, Normalise, Exit Aboriginal Australia, Arena Publications Association, Melbourne.

Anderson I. 2007. 'Remote communities: unexplained differences', Australian Policy Online, 29 June, available at <http://www.apo.org.au > [accessed 2 July 2007].

Anderson, P. and Wild, R. 2007. Ampe Akelyernemane Meke Mekarle-Little Children Are Sacred, Report of the Northern Territory Board of Inquiry into the Protection of Aboriginal Children from Sexual Abuse, Report to the Northern Territory Government, Darwin, available at $<$ http://www.nt.gov.au/dcm/inquirysaac/>

Arabena, K. 2005. ‘Not fit for modern Australian society? Aboriginal and Torres Strait Island people and the new arrangements for the administration of Indigenous Affairs', Research Discussion Paper No. 16, AIATSIS, Canberra.

Atkinson, J. 2007. 'What I would do', Australian Policy Online, 25 June, available at <http://www.apo.org.au/webboard/print-version.chtml?filename_num $=154957>$ [accessed 26 June 2007].

Attwood, B. 2003. Rights for Aborigines, Allen \& Unwin, Crows Nest, NSW.

Australian Bureau of Statistics (ABS) 2001. Housing and Infrastructure in Aboriginal and Torres Strait Islander Communities, ABS, Australian Government, Canberra.

Australian Government. 2008. 'Regional Partnership Agreements', SRAs and RPAs Website, available at <http://www.indigenous.gov.au/sra.html \#rpa $>$ [accessed 8 February 2008]. 
Behrendt, L. 2001. 'What path forward for reconciliation? The challenges of a new relationship with Indigenous people', Public Law Review, 12 (2): 79-83.

-2002. 'Unfinished journey—Indigenous self-determination', Arena Magazine, April-May, 58: 24-7.

2007. 'Shaping a nation: visionary leadership in a time of fear and uncertainty', Ninth John Curtin Prime Ministerial Library Anniversary Lecture, Curtin University, Perth.

Brough, M. The Hon. 2006a. 'Blueprint for action in Indigenous affairs', Speech as Minister for Families, Community Services and Indigenous Affairs, Indigenous Affairs Governance Series, 5 December, National Institute of Governance, University of Canberra, Canberra, available at $<$ http://www.facsia.gov.au/internet/Minister3.nsf/content/051206.htm>.

-2006b. 'Northern Territory Indigenous now free to choose', Media Release, Minister for Families, Community Services and Indigenous Affairs, 17 August, Australian Government, Canberra, .

2007. 'Government tackles overcrowding in remote Indigenous communities', Media Release, Minister for Families, Community Services and Indigenous Affairs, 8 May, Australian Government, Canberra.

and Hockey, J. The Hon. 2007. 'Jobs and training for Indigenous people in the NT', Joint Media Release, Minister for Families, Community Services and Indigenous Affairs and Minister for Employment and Workplace Relations, 23 July, Australian Government, Canberra.

Burgess, C. P. and Johnstone, F. H. 2007. Indigenous Natural and Cultural Resource Management and Health, Stakeholder debriefing paper, 8 May, Menzies School of Health Research, Charles Darwin University, Darwin.

Calma, T. 2007. 'Article muddied the waters', National Indigenous Times, Issue 124, 8 March, available at <http://www.nit.com.au/Opinion/ story.aspx $? \mathrm{id}=9849>$ [accessed 12 March 2007].

Cape York Institute for Policy and Leadership (CYI). 2007. From Hand Out to Hand Up: Cape York Welfare Reform Project Design Recommendations, CYI, Cairns.

Central Land Council (CLC). 2007. 'Commonwealth indigenous policy changes', Media Release, 22 June, Alice Springs, available at $<$ http://www.clc.org.au/media/releases/2007/cwealth_changes.asp > [accessed 23 June 2007].

Combined Aboriginal Organisations of the Northern Territory (CAONT) 2007. 'A proposed Emergency Response and Development Plan to protect Aboriginal children in the Northern Territory: a preliminary response 
to the Australian Government's proposals', 18 July, available at <http://www.racgp.org.au/news/23018> [accessed 19 July 2007].

Commonwealth of Australia 2002. Commonwealth Government Response to the Council for Aboriginal Reconciliation Final Report-Reconciliation: Australia's Challenge, AGPS, Canberra.

Council for Aboriginal Reconciliation (CAR) 2000. Roadmap for Reconciliation, CAR, Kingston, ACT.

Council of Australian Governments (COAG) 2007. 'Communique', Meeting 20 December, Melbourne.

CDEP Reform. 2007. '14 Point Action Plan for CDEP reform, 15.12.07', Unpublished paper prepared by Top End CDEP organisations following meeting of CDEP organisations with Warren Snowdon MP and Trish Crossin MP, 10 December 2007, Yirrkala.

Davis, G. and Rhodes, R. A. W. 2000. 'From hierarchy to contracts and back again: reforming the Australian public service', in M. Keating, J. Wann and P. Weller (eds), Institutions on the Edge? Capacity for Governance, Allen \& Unwin, Crows Nest, NSW.

Department of Families, Community Services and Indigenous Affairs (FaCSIA). 2006. 'Access to Aboriginal land under the Northern Territory Aboriginal Land Rights Act - time for a change?' Discussion Paper, October, Canberra.

Dillon, A. 2005. 'Separatism', Occasional Paper, November, The Bennelong Society, Melbourne.

- and Westbury, N. 2007. Beyond Humbug: Transforming Government Engagement with Indigenous Australia, Seaview Press, West Lakes, SA.

Dodson, M. 1996. 'Assimilation versus self-determination: no contest', Northern Australia Research Unit (NARU) Discussion Paper No. 1, NARU, ANU, Darwin.

- and Pritchard, S. 1998. 'Recent developments in Indigenous policy: the abandonment of self-determination?' Indigenous Law Bulletin, 4 (15): 4-6.

— and Smith, D. 2003. 'Governance for sustainable development: strategic issues and principles for Indigenous Australian communities', CAEPR Discussion Paper No. 250, CAEPR, ANU, Canberra.

and Strelein, L. 2001. 'Australia's nation-building: renegotiating the relationship between Indigenous peoples and the state', University of NSW Law Journal, 24 (3), available at <http://www.austlii.edu.au/ au/journals/UNSWLJ/2001/68.html $>$ [accessed 2 July 2007]. 
and McCarthy, D. 2006. 'Communal land and the amendments to the Aboriginal Land Rights Act (NT)', Research Discussion Paper No. 19, Native Title Research Unit, AIATSIS, Canberra.

Dodson, P. 1996. 'Reconciliation at the crossroads', Address to the National Press Club of Australia, April, Canberra, available at $<$ http://www.austlii.edu.au/au/special/rsjproject/rsjlibrary/car/ dodson.html> [accessed 2 July 2007].

2007. 'An entire culture is at stake', The Age, 14 July, p. 9.

Education and Health Standing Committee (EHSC) 2007a. 'Initiatives in the remote Indigenous communities of Cape York', Report No. 7 in the 37th Parliament, Legislative Assembly, Parliament of Western Australia, Perth.

EHSC 2007b. 'Where from? Where to? A discussion paper on remote Aboriginal communities', Report No. 6 in the 37th Parliament, Legislative Assembly, Parliament of Western Australia, Perth.

Elu, J. 2007. 'Embracing economic development to achieve economic independence', Paper presented to Tides of Native Title conference, 6-8 June, Cairns.

Finlayson, J. 2004. Success in Aboriginal Communities: A Pilot Study, AIATSIS, Canberra.

2005. 'Guest Editorial', Australian Aboriginal Studies, 2: 1-3.

Gaita, R. 2007. 'Comment', The Monthly, August: 10-14.

Gilligan, B. 2006. The Indigenous Protected Areas Programme: 2006 Evaluation, Department of the Environment and Heritage, Commonwealth of Australia, Canberra, available at <http:/www.deh.gov.au/indigenous/ publications/ipa-evaluation.html $>$ [accessed 3 July 2007].

Grattan, M. 2007. 'Aboriginal group lashes PM's plan', The Age online, 11 July, available at <http://www.theage.com.au/news/national/aboriginalgroup-lashes-pms-plan/2007/07/10/1183833519338.html?page=fullpage $>$ [accessed 11 July 2008].

Gray, B. and Sanders, W. 2006. 'Views from the top of the "quiet revolution": secretarial perspectives on the new arrangements in Indigenous affairs', CAEPR Discussion Paper No. 282, CAEPR, ANU, Canberra.

Hart, V., Herbert, J. and Tripcomy, P. 2004. 'Accountability the key to change through education', National Indigenous Times, 24 November, p. 69, available at <http://www.nit.com.au/Opinion/story.aspx?id=4067> [accessed 2 July 2007]. 
Hinkson, M. 2007. 'Introduction: in the name of the child', in J. Altman and M. Hinkson (eds), Coercive Reconciliation: Stabilise, Normalise, Exit Aboriginal Australia, Arena Publications Association, Carlton.

House of Representatives Standing Committee on Aboriginal Affairs (HRSCAA) 1990. Our Future Our Selves: Aboriginal and Torres Strait Islander Community Control, Management and Resources, Commonwealth of Australia, AGPS, Canberra.

Howard, J. W. The Hon. 2007a. Address to 'Their Spirit Still Shines', Commemorating the $40^{\text {th }}$ Anniversary of the 1967 Referendum Parliament House, 27 May, Canberra.

2007b. Address to the Sydney Institute, 25 June, Four Seasons Hotel, Sydney.

Hunt, J. and Smith, D. 2006. 'Building Indigenous community governance in Australia: preliminary research findings', CAEPR Working Paper No. 31, CAEPR, ANU, Canberra.

- and -2007. 'Indigenous Community Governance Project: year two research findings', CAEPR Working Paper No. 36, CAEPR, CASS, ANU, Canberra.

Hughes, H. 2007. Lands of Shame: Aboriginal and Torres Strait Islander 'Homelands' in Transition, The Centre for Independent Studies Ltd, St Leonards, NSW.

Jeffries, S. 2006. 'Shared responsibility: mutual obligation', Background Briefing, ABC Radio National, 12 March.

Johns, G. 2006. 'Social stability and structural adjustment', Paper presented to Leaving Remote Communities, Bennelong Society Sixth Annual Conference, 1-2 September, Sydney.

Koori Mail. 2007. 'Axe falls on CDEPs', 4 July, p. 12.

Law Reform Commission of Western Australia 2006. Aboriginal Customary Laws: The Interaction of Western Australian Law with Aboriginal Law and Culture, Final Report, Project 94, Government of Western Australia, Perth.

Leach, M. Bloom, G. Ely, A. Nightingale, P. Scoones, I. Shah, E. and Smith, A. 2007. 'Understanding governance: pathways to sustainability', STEPS Working Paper 2, STEPS Centre, Brighton.

McCarthy, M. MLA. 2006. 'Adjournment debate', Parliamentary Record No. 6, Legislative Assembly of the Northern Territory, Tenth Assembly, First Session, 29 March, Darwin. 
McCausland, R. 2005a. 'The "new mainstreaming" of Indigenous affairs', Briefing Paper No. 3, Ngiya Institute for Indigenous Law, Policy and Practice, Jumbunna Indigenous House of Learning, University of Technology, Sydney.

_2005b. 'Shared Responsibility Agreements', Briefing Paper No. 1, Ngiya Institute for Indigenous Law, Policy and Practice, Jumbunna Indigenous House of Learning, University of Technology, Sydney.

Morgan, Disney and Associates Pty Ltd. 2006a. A Red Tape Evaluation in Selected Indigenous Communities, Final Report for OIPC, Canberra.

— with Tracey Whetnall Consulting and Wis-Wei Consulting Pty Ltd. 2006b. Synopsis Review of the COAG Trial Evaluations, Report to OIPC, Canberra.

Morrisey, M. 2006. 'The Australian state and Indigenous people 1990-2006', Journal of Sociology, 42 (4): 347-54.

Moreton-Robinson, A. 2007. 'Introduction', Sovereign Subjects: Indigenous Sovereignty Matters, Allen \& Unwin, Crows Nest.

Murdoch, L. 2007. 'Macklin quarantines welfare, calls summit on intervention', The Age, 11 December, available at <http:/www.theage.com.au/news/ national/macklin-quarantines-welfare-calls-summit-on-intervention/2007/ 12/10/1197135374439.html> [accessed 11 December 2007].

National Indigenous Council (NIC). 2006. Report to Government January-December 2006, available at <http://www.atsia.gov.au/NIC/reports.aspx > [accessed 15 June 2007].

Office of Indigenous Policy Coordination (OIPC) 2005. New Arrangements in Indigenous Affairs, DIMIA, Australian Government, Canberra.

-2007. 'Regional Indigenous engagement arrangements', OIPC, available at $<$ http://www.oipc.gov.au/documents/RegionalIndigenousEngagement Arrangements_Parameters.pdf> [accessed 18 December 2007].

Pearson, N. 2000. Our Right to Take Responsibility, Noel Pearson and Associates, Cairns, QLD.

2005a. 'Can Cape York communities be economically viable?' Viewpoint, November, CYI , Cairns, QLD.

-2005b. 'The Cape York Agenda', Speech to the National Press Club of Australia, 30 November, Canberra.

2006. 'Address to the Treasury on the Cape York Peninsula reform agenda', Commonwealth Department of Treasury, 25 September, Canberra.

2007a. 'Give us help to help ourselves', The Weekend Australian, 17-18 March, p. 28. 
2007b. 'Action only way forward', The Weekend Australian, 7-8 July, p. 23.

PricewaterhouseCoopers 2007. Living in the Sunburnt Country-Indigenous Housing: Findings of the Review of the Community Housing and Infrastructure Programme, Final report to FaCSIA, February, Canberra.

Reconciliation Australia (R. Withers and R. Beattie [eds]). 2006. Celebrating Indigenous Governance: Success Stories of the Indigenous Governance Awards, RA, Canberra.

Rhodes, R. 2005. 'The unholy trinity of governance', The Blake Dawson Waldron Lecture, 23 August, National Museum of Australia, Canberra.

Ross, D. 2007. 'Permits protect,' in J. Altman and M. Hinkson (eds), Coercive Reconciliation: Stabilise, Normalise, Exit Aboriginal Australia, Arena Publications Association, Carlton, VIC.

Rowse, T. 2005. 'The Indigenous sector', in D. Austin-Broos and G. Macdonald (eds), Culture, Economy and Governance in Aboriginal Australia: Proceedings of a Workshop of the Academy of the Social Sciences in Australia held at the University of Sydney 30 November-1 December 2004, University of Sydney Press, Sydney.

Royal Commission into Aboriginal Deaths in Custody (RCIADIC) 1991. National Report, Volume 4, available at <http:/www.austlii.edu.au/au/other/ IndigLRes/rciadic/national/vol4/5.html > [accessed 3 July 2007].

Sanders, W. 2004. 'ATSIC's achievements and strengths: implications for institutional reform', Journal of Australian Indigenous Issues, 7 (3): 14-21.

-2006. 'Indigenous affairs after the Howard decade: an administrative revolution while defying decolonization', Paper presented to the John Howard's Decade conference, 3-4 March, ANU, Canberra.

-2007a. 'Changes to CDEP under DEWR: policy substance and the new contractualism', Topical Issue No. 6, CAEPR, ANU, Canberra.

2007b. 'The contraction of the CDEP scheme under new management after thirty good years: growing old or returning to remote area origins in times of low unemployment?' Paper presented in CAEPR Seminar Series I, 23 May, CAEPR, ANU, Canberra.

Sanderson, Lt Gen J. 2007. 'Federal renewal and unity in reconciliation: a return to government by the people', Annual Oration 2007, Order of Australia Association, available at <http://www.theorderofaustralia.asn.au/news/ initiatives_and_activities.php $>$. 
Scrymgour, M. MLA. 2007. 'Comments On Mantiyupwi Negotiating Team Document' Dated 20/5/07, Member For Arafura, 21 May, Northern Territory Government, Darwin.

Secretaries Group on Indigenous Affairs (SGIA) 2005. Secretaries Bulletin, 1, available at <http://www.apsc.gov.au/indigenousemployment/ bulletin0105.htm $>$ [accessed 8 September 2006].

Sen, A. 1999. Development as Freedom, Oxford University Press, New York.

Shergold, P. 2005. 'Delivering services to Indigenous Australians-a whole-of-government approach', Presentation to the Australian Government Indigenous Affairs Forum for the Northern Territory, 17 February, Darwin.

Shire of Naaanyatjarruku and Ngaanyatjarra Council 2007. Response to Western Australia Legislative Assembly Education and Health Standing Committee: Discussion Paper on Remote Communities.

Siewart, R. The Hon. 2007. 'Ministerial powers to seize assets of service providers in prescribed areas within the Northern Territory', Background Briefing, Parliament House, Canberra, available at $<$ http://www.rachelsiewert.org.au/files/campaigns/extras/Briefing on_NT_seizure_powers.pdf $>$.

Smith, D. 2004. 'From Gove to governance: reshaping Indigenous governance in the Northern Territory', CAEPR Discussion Paper No. 265, CAEPR, ANU, Canberra.

-2006. 'Evaluating governance effectiveness: a facilitated process with the Board of Yarnteen Aboriginal and Torres Strait Islanders Corporation', ICGP Case Study Report No. 2, ICGP, CAEPR, ANU, Canberra.

-2007a. 'Networked governance: issues of policy, power and process in a West Arnhem Land regional initiative', Ngiya: Talk the Law, 1: 24-52.

-2007b. 'From COAG to coercion: a story of governance failure, success and opportunity in Australian Indigenous affairs', Paper presented to the Governing Through Collaboration: Managing Better Through Others conference, Australia and New Zealand School of Government (ANZOG), 28-9 June, Canberra,.

Steering Committee for the Review of Government Service Provision (SCRGSP) 2003. Overcoming Indigenous Disadvantage: Key Indicators 2003 Report, Commonwealth of Australia, Canberra.

2007. Overcoming Indigenous Disadvantage: Key Indicators 2007 Report, Commonwealth of Australia, Canberra. 
Taylor, J. 2006. 'Population and diversity: policy implications of emerging Indigenous demographic trends', CAEPR Discussion Paper No. 283, CAEPR, ANU, Canberra.

Vanstone, A. (The Hon.) 2005. 'Beyond conspicuous compassion: Indigenous Australians deserve more than good intentions', Address as Minister for Immigration and Multicultural and Indigenous Affairs to the Australia and New Zealand School of Government, 7 December, ANU, Canberra.

Westbury, N. and Dillon, M. 2006. 'Australia's institutionalised second class', The Australian Financial Review, 8 December.

Whitby, T. 2001. 'Reforming the CDEP Scheme', in F. Morphy and W. Sanders (eds), The Indigenous Welfare Economy and the CDEP Scheme, CAEPR Research Monograph No. 20, CAEPR, ANU, Canberra. 